\title{
A new species of Liothrips from the Amazonas harmful to Guarana plantations (Insecta: Thysanoptera: Phlaeothripidae)
}

\author{
Richard zur Strassen ( ${ }^{*}$ )
}

\begin{abstract}
One of the Thysanoptera species collected from Guarana plantations in the Amazonas basin has proved to be hitherto unknown to science and is described as Liothrips adisi $\mathrm{n}$. sp.
\end{abstract}

\section{INTRODUCTION}

During the year 1976 great parts of Guarana plantations in the vicinity of Manaus, Amazonas (Brasil) were infested by thrips (Adis, 1977, in prep.). The majority of these thrips attacked mostly the flower buds, tender leaves and the young shoots of the cultivated guarana plants, Paullinia cupana sorbilis Martius \& Ducke (family Sapindaceae). Joachim Adis of the Instituto Nacional de Pesquisas da Amazônia [INPA] in Manaus collected a number of specimens of the harmful species of thrips. I am grateful to him for the opportunity to study the new species which is named after him.

The holotype and some paratypes will be deposited in the above institute (INPA), further paratype specimens are preserved in the Forschungsinstitut and Naturmuseum Senchenberg in Frankfurt am Main [SMF], in the Department of Entomology of the British Museum (Natural History) in London and in the Smithsonian Institution in Washington.

Liothrips adisi n. sp. (Fig. 1-2)

Holotype: $q$ (deposited in INPA), Brasil, Manaus (Amazonas), from young leaves of Paullinia cupana var. sorbilis Martius \& Ducke (Sapindaceae), 24-VII-1976, leg. Joachim Adis.

Paratypes: 2 \& 6 of 2 larvae (INPA) and 5 우 5 of 2 larvae (SMF T 7304) together with the holotype.

\section{DIAGNOSIS}

A dark winged species of intermediate size with head 1.1-1.2 times as long as broad, all tibiae and tarsi dark, only antennal segment III clear yellow, prothorax on each side with two epimeral setae of different length, main body setae dark including those on abdominal segments VIII-X, their tips blunt or slightly knobbed, anterior wing with 10-16 duplicated cilia, tube in $\&$ slightly shorter than in $\delta$, about as long as the head, dorsal setae on tergite IX longer than the tube, in of seta S2 on tergite IX longer than S1, not short and spine-like.

\section{DESCRIPTION}

\&, macropterous, total body length (distended) $2250-3000 \mu \mathrm{m}$.

Body including legs uniformly black, fore tibia sometimes brown in distal half, antenna dark, only segment III clear yellow, rarely slightly tinged apically with brown; wings brown, darkest at base, gradually becoming paler towards tip, anterior wing with a broad longitudinal median bar; main setae dark including the dorsal ones on abdominal segnients VIII-X, but lateral (= posteroangular) setae on pleurotergites IV-VII and seta S2 on sternites V-VIII yellow or brownish yellow.

Head (fig. 1) 1.1-1.2 times as long as broad, broadest immediately behind eyes, cheeks straight, distinctly converging towards base, the latter somewhat constricted. Eyes occupying $33-37 \%$ of the lateral margin of head. Anterior ocellus just overhanging interantennal process. Postocular seta 105-121 $\mu \mathrm{m}$ long, placed 22-31 $\mu \mathrm{m}$ behind posterior margin of eyes, their tips blunt, often slightly expanded; other setae minute, even those along

$(\cdot)$ - Frankfurt am Main. 
cheeks, Mouth cone relatively short, somewhat bulged around middle, then strongly narrowed to apex. Antenna (fig. 2) about 1.7-1.9 times as long as the head, intermediate segments not particularly elongated, segment III about 2.2 times as long as broad, IV little shorter than or as long as III, but definitely broader than III, V and $\mathrm{VI}$ about equal in length and each 2.2-2.3 times as long as broad; total length $480-525$ $\mu \mathrm{m}$. Length (L) and width (W) in $\mu \mathrm{m}$ of antennal segments:

$\begin{array}{llccc} & & & \text { L } & \text { W } \\ \text { I } & \ldots \ldots \ldots \ldots \ldots & 40-43 & 40-43 \\ \text { II } & \ldots \ldots \ldots \ldots \ldots \ldots & 50-57 & 32-34 \\ \text { III } & \ldots \ldots \ldots \ldots \ldots \ldots & 75-86 & 33-35 \\ \text { IV } & \ldots \ldots \ldots \ldots \ldots & 74-86 & 41-44 \\ \text { V } & \ldots \ldots \ldots \ldots \ldots & 69-75 & 33-34 \\ \text { VI } & \ldots \ldots \ldots \ldots \ldots & 68-73 & 32-33 \\ \text { VII } & \ldots \ldots \ldots \ldots \ldots & 52-63 & 24-25 \\ \text { VIII } & \ldots \ldots \ldots \ldots \ldots & 34-37 & 11-12\end{array}$

Pronotum (fig. 1) comparatively short, 0.5-0.6 times the head length and 0.6 times as long as the distance between the posteroangular setae, its median length 129-155 $\mu \mathrm{m}$, width across anterior margin 218-240 $\mu \mathrm{m}$, greatest width $327-373 \mu \mathrm{m}$. All main prothoracic setae developed, their tips blunt or slightly knobbed, anteroangulars and mediolaterals sometimes little expanded, epimeron with two stout setae, the inner one much shorter than the outer one; length of anteromarginals $46-49 \mu \mathrm{m}$, anteroangulars 52-68 $\mu \mathrm{m}$, mediolaterals $75-98 \mu \mathrm{m}$, posteroangulars 120-157 $\mu \mathrm{m}$, inner epimerals 40-68 $\mu \mathrm{m}$, outer epimerals 109-172 $\mu \mathrm{m}$. Surface with few scattered transverse lines in front of posterior margin.

Pterothorax 356-459 $\mu \mathrm{m}$ long, 459-517 $\mu \mathrm{m}$ broad. Mesonotum 103-121 $\mu \mathrm{m}$ long, 298-344 $\mu \mathrm{m}$ broad, surface densely sculptured with transverse anastomosing lines, lateral setae blunt or slightly knobbed, 54-67 $\mu \mathrm{m}$ long. Metanotum 241-282 $\mu \mathrm{m}$ long, 298-355 $\mu \mathrm{m}$ broad, densely sculptured with longitudinal hexagons, discal seta 57-69 $\mu \mathrm{m}$ long, somewhat thinner than the lateral seta of mesonotum, tip narrowly rounded. Anterior wing 990-1160 $\mu \mathrm{m}$ long, 86-126 $\mu \mathrm{m}$ broad across scale and 95-112

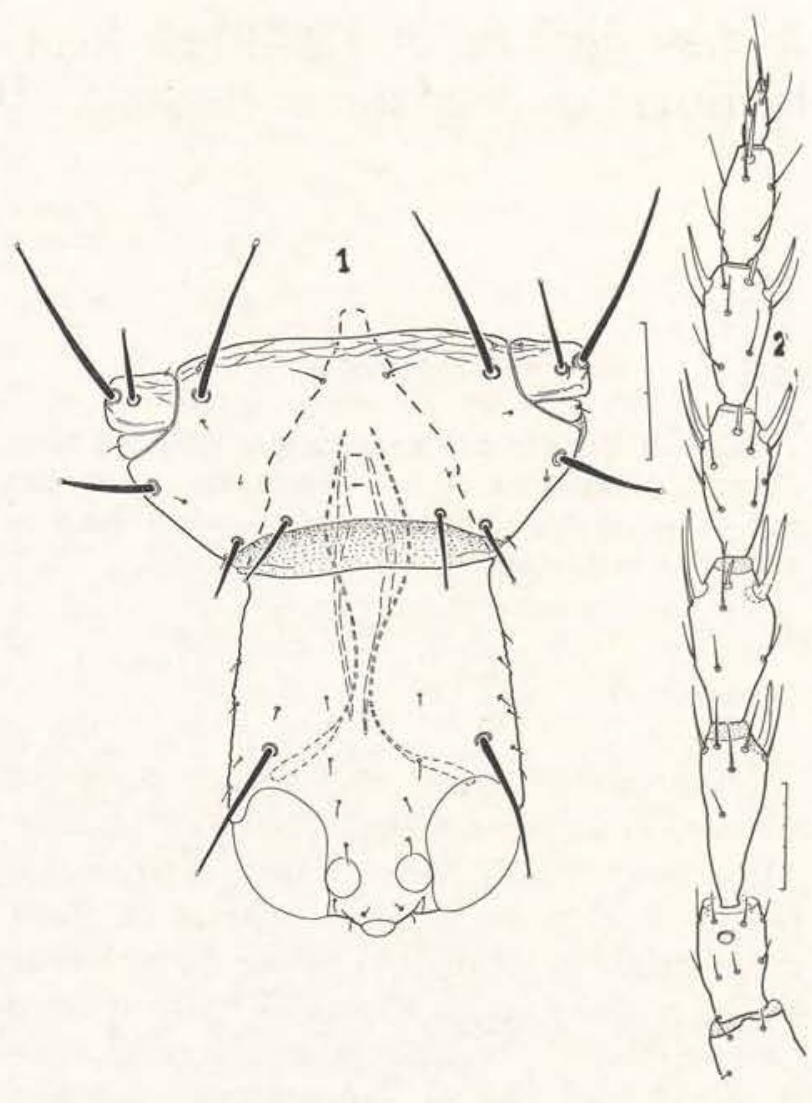

Fig. 1-2 - Liothrips adisi n. sp.,..-1$)$ Head and pronotum; specimen KOH-treated, head slightly tilted, scale $100 \mu \mathrm{m}$. 2) Right antenna dorsal; scale $50 \mu \mathrm{m}$. - J.S. Bhatti del.

$\mu \mathrm{m}$ broad across middle, subbasal wing setae knobbed or slightly expanded at tip, length of S1: 75-92 $\mu \mathrm{m}, \mathrm{S} 2: 86-103 \mu \mathrm{m}, \mathrm{S} 3:$ 93-109 $\mu \mathrm{m}$; hind margin with 12-16 duplicated cilia.

Abdomen as usual. Pelta triangular in shape, 115-138 $\mu \mathrm{m}$ long, 184-239 $\mu \mathrm{m}$ broad, surface with hexagonal sculpture. Tergite IX 113-122 $\mu \mathrm{m}$ long, $220-243 \mu \mathrm{m}$ broad, main setae pointed, length of S1: $252-287 \mu \mathrm{m}, \mathrm{S} 2: 292-321$ $\mu \mathrm{m}, \mathrm{S} 3: 270-321 \mu \mathrm{m}$. Tube slightly shorter than both the head and the main setae on tergite IX, lateral margins converging apically somewhat less in basal third than in the distal two-thirds, length of tube 235-255 $\mu \mathrm{m}$, width at base $109-115 \mu \mathrm{m}$ width at hind margins $47-49$ $\mu \mathrm{m}$; length of longest terminal seta $195-258 \mu \mathrm{m}$.

Some measurements of holotype $\&$ in $\mu \mathrm{m}$ $(\mathrm{L}=$ length, $\mathrm{W}=$ width): Total $\mathrm{L} 2920$; head L 263, greatest W 235, W across eyes 230 , across base 199, eye dorsal L 103, mouth cone 
L 218, antenna L 515; pronotum L 149, W across anterior margin 223, greatest W 356 , anteromarginal seta $L 63$, anteroangular $L 60$, mediolateral $L$ 92, posteroangular $L 149$, inner epimeral L 57, outer epimeral L 172, anterior tibia L 258; pterothorax L 430, W 498, mesonotum L 106, W 333, metanotum L 281, W 327, anterior wing $L 1132, W$ across scale 115 , across middle 109, posterior wing $L$ 1004; pelta L 132, W 228, tergite IX L 118, W 241, seta S1 L 276, S2 L 304, S3 L 321, tube L 253 , W across base 115 , longest terminal seta $L$ 258.

i , macropterous, total body length (distended) $2320-2450 \mu \mathrm{m}$.

Like female in colour and general structure, somewhat smaller and more slender than female, head somewhat more distinctly narrowed towards base than in female, fore leg not enlarged, fore tarsus without tooth, seta S2 on tergite IX longer than S1, not short and spine-like.

Measurements of small and large paratype $\delta$ in $\mu \mathrm{m}(\mathrm{L}=$ length, $\mathrm{W}=$ width). Total $\mathrm{L}$ 2320-2450; head L 230-252, greatest W 199.212, $W$ across base 166-173, eye dorsal $t$ 92-98, mouth cone L 148-156, antenna L 400-460; pronotum L 121-132, greatest W 294-310, anteromarginal seta L 52-57, anteroangular L 46-57, mediolateral 75-86, posteroangular L 100-109, inner epimeral L 34-61, outer epimeral 114-128; pterothorax L 356-390, mesonotum L 95-99, W 261-270, lateral seta L 52-57, metanotum L 224-236, W 264-281, discal seta 51-57, anterior wing $L$ 900-947, W across scale 92-98, across middle 81-86; pelta L 108-112, W 161-218, tergite IX L 103-110, W 152-168, seta S1 L 252-264, seta S2 L 270-283, seta 83 L 278-293, tube L 230-247, W across base 86-98, longest terminal seta L 207-241.

Larva II: Coloration orange-yellow with head, the whole antenna, the two pronotal plates, all legs, the two small plates at the posterior angles of tergite VIII and the abdominal segments IX and X black; body setae pale brown, the midlateral ones on abdominal segments yellowish brown, all knobbed or slightly expanded at tip.

Total length 1650-1900 $\mu \mathrm{m}$. Head 120-132 $\mu \mathrm{m}$ long, postocular seta $47-54 \mu \mathrm{m}$ long; an- tenna 321-362 $\mu \mathrm{m}$ long, distance between their sockets 30-34 $\mu \mathrm{m}$, segment III 86-102 $\mu \mathrm{m}$ long, 23-24 $\mu \mathrm{m}$ broad, segment IV 57-69 $\mu \mathrm{m}$ long, 25 $\mu \mathrm{m}$ broad. Pronotal plates each 143-155 $\mu \mathrm{m}$ long, width across both plates 230-270 $\mu \mathrm{m}$, length of seta S1: $25-29 \mu \mathrm{m}, \mathrm{S} 2: 34-43 \mu \mathrm{m}, \mathrm{S} 3$ : 69-80 $\mu \mathrm{m}, \mathrm{S} 4:$ 58-72 $\mu \mathrm{m}, \mathrm{S} 5: 94-110 \mu \mathrm{m}, \mathrm{S} 6$ : 114-138 $\mu \mathrm{m}, \mathrm{S} 7: 63-80 \mu \mathrm{m}$. Setae $\mathrm{S} 1$ and $\mathrm{S} 2$ on hind margin of the lateral plates on tergite VIII 51-67 $\mu \mathrm{m}$ long. Abdominal segment IX 126-161 $\mu \mathrm{m}$ long, 103-128 $\mu \mathrm{m}$ broad across anterior margin, 86-103 $\mu \mathrm{m}$ broad across posterior margin, the setae of all three posteromarginal pairs of about equal length (103-126 $\mu \mathrm{m})$. Segment $X$ 112-120 $\mu \mathrm{m}$ long, 75-87 $\mu \mathrm{m}$ broad at base, longest terminal seta 200-258 $\mu \mathrm{m}$.

\section{Discussion}

Liothrips adisi $\mathrm{n}$. sp. belongs to those species which are characterised by the fairly short head being only 1.1-1.2 times as long as broad, by the presence of two short epimeral setae and by the long seta $\mathrm{S} 2$ on tergite IX in $\delta$. The species seems to be closely related to $L$. varicornis Hood 1912 from North America and Mexico, but is distinguished (1) by the dark setae on abdominal segments VIII-X (pale in varicornis), (2) by the coloration of the anterior wing which is darkest at base, becoming paler gradually towards apex (in varicornis pale at base, except for the insertion area of the subbasal setae, and becoming slightly darker in distal half), and (3) in the somewhat heavier and stouter setae on head and pronotum as compared with those in varicornis. Another similar species is $L$. obscuricornis Priesner from Paraguay which differs from adisi $\mathrm{n}$. sp. (1) in the more slender head being 1.4 times as long as broad (in adisl 1.1-1.2 times), (2) in the paler intermediate antennal segments with IV-VI mottled yellow. ish (in adisi uniformly dark), and (3) in the more elongate antennal segments $\mathrm{V}$ and $\mathrm{VI}$, with $\mathrm{V} 2.7$ times as long as broad (in adisi 2.1-2.2 times) and $\mathrm{VI}$ about 0.7 times as leng as $\mathrm{V}$ (in adisi $\mathrm{V}$ and $\mathrm{VI}$ of equal length). $L$. cordiae Hood 1935 from Panama also shows resemblances with adisi, but is characterised 
(1) by the slightly more elongate head which is 1.3 times as long as broad, (2) by the yellowish brown distal part of antennal segment II, (3) by the minute inner epimeral seta, (4) in the black lateral abdominal setae (= posteroangulars of pleurotergites), (5) by the pale (brownish yellow) setae S1 to S3 on tergite $\mathrm{IX}$ in $q$, and (6) by the short spine-like setae $\mathrm{S} 2$ on tergite $\mathrm{IX}$ in $\delta$.

DERIVATHO NOMINIS: The species is named after its collector, Dipl. - Biol. J. Adis.

\section{Resumo}

No $2 .^{\circ}$ semestre de 1976 houve uma série infestaçăo por trips, das inflorescências jovens, brotos e folhas jovens de guaraná, em plantaçôes próximas a Manaus. Um desses Thysanoptera era uma espécie nova e é aqui descrita como Liothrips adisi n. sp. L. adisi pertence ao grupo de espécie caracteri- zadas por uma cabeça muito curta, pela presença de setas epimerais e por ter a seta S2 comprida, no tergito IX do ô. A espécie é próxima de $\mathbf{L}$. va ricornis da América do Norte e $\mathbf{L}$. obscuricornis do Paraguai e, mais distante um pouco, de L. cordiae do Panamá.

\section{LITERATURE CITED}

Hoop, J.D.

1912 - New genera and species of North American Thysanopters from the South and West. Proc. Biol. Soc. Washington, 25: 61-76.

1935 - Ten new Thysanoptera from Panama. Proc. Biol. Soc. Washington, 48:83-106.

Priesner, $\mathrm{H}$.

1921 - Neue und wenig bekannte Thsanopteren der neotropischen Fauna aus der Sammlung des Berliner Zoologischen Museums. Deutsche ent. Z., 3:187-223. 